\title{
The Impossibility of Verifying Reality in Harold Pinter's Old Times
}

\author{
Noorbakhsh Hooti \\ English Department, Faculty of Arts, Razi University, Kermanshah, Iran \\ Email: nhooti@yahoo.com
}

\begin{abstract}
This study is an attempt to show the unreachable depth of reality in Pinter's Old Times. Pinterian dramatic dialogue proceeds deliberately through a serpentine terrain with scattered boulders of disturbing, menacing questions-without-answers, leading invariably to further awkward repetitions, pleonasms, nonsquiturs, gaps and potholes of uneasy pauses and of heavily loaded silences. In Old Times, it has been brilliantly dramatized that the distinction between real and unreal or true and false can hardly be determined with certainty. What, therefore, Pinter projects is not an imitation of reality, but a theatrical extension of reality. Conversations that take place in a Pinter's play are quite different from those of real life. Pinterian actors require a specialized know-how for putting in exact theatrical expression to the sub-textual language. The study further tries to show that behind the expressed vocabulary, there looms large the unexpressed hidden territory. The characters must probe beneath the apparent, to get at the inner stream of imageshorizontally, vertically, diagonally.
\end{abstract}

Index Terms - Old Times, reality, territory, Pinterian, study

\section{INTRODUCTION}

The aim of this study is to illuminate the notion of Reality in Pinter's Old Times through the oscillating journey of the characters from past to present and vice versa, which seems vague and complicated. This journey is vividly introduced through the typical Pinterean dialogue.

Joseph and Roberts (2004) believe:

The most fundamental conviction for any form of realism is a belief in the independent existence of a real world. The particular way that critical realism understands this is through the distinction between transitive knowledge and the intransitive mind-independent objects that this knowledge is of. Our transitive knowledge is embodied in theories, practices, discourses and texts. Critical realism argues that this transitive knowledge is socially and historically located and engendered.(p.2)

Old Times is no less distinguished by pauses and silences that invest the Pinterian dialogue with strange ambiguous meaning. The play, underlining the subtle struggle for psychological power, steeped in an atmosphere which blends everyday reality with dream- images. The play also introduces an intruder, as do the earlier plays, who threatens the prevailing peaceful mode of life, and registers similar battle for territory for possession of an individual. Besides, the play has a strong undercurrent of sexual overtones. In Old Times Pinter's dialogue creates the appropriate dramatic tone which is new and poetically compelling. The shifting perspectives on the past, the inadequate grip characters have on truth and reality give rise to a threatening world in which the desire for verification, the need for all knowledge and genuine communication is necessarily frustrated. Through the dialogue Old Times divulges the malignant element usually hidden in human life, a common Pinter theme.

In Old Times Pinter shows us that a play in its broadest definition is a personal, direct impression of life. Its value is greater or lesser in accordance with the intensity of the impressions of the individuals. The playwright knows that physical performance expresses inner conflicts and resolution. He uses a theatre language capable of carrying forward these sense impressions. There is the colloquially based verbal game people play in their social interchanges. The dialogue of the three characters raises the question whether the characters tell lies to one another. Can they make the audience aware that they are lying? The answers may emanate out of the accentuation and intonation, giving a clue either of assertion or neutrality. The significant aspect of dramatic dialogue happens to be its latent heat or the various degree of suggestiveness. From this standpoint it may be said that Pinter's play is a dramatic text which defines its own context through its dialogue.

Old Times through its placid dramatic language gives us a deep sense that life escapes, a sense that Virginia Woolf wanted to convey: "Look within and life, it seems, is very far from the beginning of consciousness to the end" (Kettle, 1953, p. 91). Old Times is made as a picturesque tableau chiefly through its dialogue having multidimensional connotations.

Dialogue works through specially chosen words culled out, with an acute observation, from the mannerisms, repetitions and clichés of the English vernacular as spoken in real life. Between the characters of Old Times words are exchanged as potent weapons of dominance and subservience. Pauses and silences are awfully meaningful in the 
literary sense. What resembles tape-recorded vocabulary is nevertheless, highly stylized. In Old Times(1981, henceforth Pinter) Pinter shows his total capability in approximating human reality with that artistic attempt to capture the given moment and set it above the uncertainties which time brings all the way through its passage:

Anna: Why don't you try her yourself?

Deeley: Would you recommend that?

Anna: You'd do it properly.

Deeley: In her bath towel?

Anna:How out?

Deeley: How out?

Anna: How could you dry her out? Out of her bath towel?

Deeley: I don't know.

Anna: Well, dry her yourself, in her bath towel.

(Pause) (pp. 50-51)

Old Times has a very satisfying shape, structure and an overall dramatic unity, all of which are of a very different kind from those of the conventional plays. The play is basically a series of conversation between three characters, Anna, Kate, Deeley, who from a clear love triangle. Their dialogue, woven mostly around the episode of the past, attempts to define the nature of the relationship which existed and gradually came to stay in between them. Their conversation in bits and pieces leads to an awareness of the distance by which they have been alienated. Bryden, the reviewer of the first night of Old Times, comments pertinently on the dialogue by referring to " the valuer of each word and silence which exposes every layer of the text like the person of a three-dimensional chess-board" (Bryden, 1971, p. 179).

An audience with an ear for Pinter's dialogue recognizes the territory upon which Old Times stands. The complex rhythm of the dialogue strikes the note of a conflict for dominance and possession. The combat ground indeed is Kate; the two contenders to possess her are Anna, her one-time room-mate and only friend, and Deeley, her husband. The ammunition used in the skirmish is indeed dramatic dialogue. Language of innuendo and ambiguous menace abounds in the play. As in "The Homecoming", the winner here will be the one who would ultimately impose his or her language upon the other in getting the upper hand.

In The Homecoming Ruth and Lenny exchange blows; in Old Times it is between Anna and Deeley that blow follows blow and parry in terms of the skilled game of lingual gambits and manoeuvres. Whereas Deeley, Kate's husband, wields crude power with Kate under his physical control, Anna has a patient finess, the authority of money and culture, a cold determination. Kate's vague, smiling passivity appears to be on Anna's side. The dialogue of the play "participates in the new Pinter world of maximum compression and austere poetry first heard in Landscape and Silence"'(Baker and Tabachnich, 1973, p. 137).

The dramatic action of Old Times takes place in a converted country frame house of Deeley and his wife Kate, who are waiting the arrival from Sicily in Italy of Kate's old friend Anna whom Kate has not seen for the last twenty years. Her arrival subtly menaces the marriage of Kate as she tries calculatedly to recreate her very close friendship with Kate, which Deeley has got into as an intruder by marrying Kate. Anna enters the secluded household of Deeley and Kate to struggle for a position of dominance. It recurs with an insidious force superbly manifested through the masterly fashioned dialogue with verbal variations cut out for the individual characters:

Deeley: Yes, I remember you quite clearly from The Wayfarers.

Anna: The what?

Deeley: The Wayfarers Tavern, just off the Brompton road.

Anna: When was that?

Deeley: Years ago.

Anna: I don't think so.

Deeley: Oh yes, it was you, no question. I never forget a face. (Pinter, pp. 44-45).

The combat for territory between Deeley and Anna for the possession of Kate with all her individuality emerges gradually from their glib conversation and soon explodes into the uncomfortable, rather surrealist, memories of the past. Old Times upholds the usual male-female scuffle found in Pinter's world and endemic to human race as well. Deeley, a successful, widely travelled film maker, uses masculine power and blunt coarseness to encounter Anna's indirect and sly attack. The dramatic dialogue in Old Times weaves the pattern of attack and defence in which all the three characters are locked.

Old Times deals with the element of time, space and the related concept of memory of the dim distant past. The play attempts to capture the past, to co-relate eternal time with spatial time and to recreate the effect of the past on the present through memory lane. Its dialogue relates to the past of all the three characters, and is broken up by extended stories which in their turn relate again to the past with reference to space in time. Almansi and Henderson aptly comment that, "the characters in Old Times enter a sort of time-machine" (1983, p. 91). Kate confronts her girl friend Anna from the hazy past, and thereupon hidden and shelved memories start spilling out once again though it is difficult to ascertain the truth.

A close examination of the dramatic dialogue reveals that there is a strong undercurrent of suggestion that Kate and Anna could well have been involved in a lesbian relationship. It is also suggested that there could have a close touch 
between Anna and Deeley in the past. Gradually, as the play unfolds its net, Deeley the single man of the triangle is left with a sense of separation from both women. Their conversation shows that Pinter, being quite intent on mystification, withholds essential information. In this context, Nightingale's observation is quite relevant: "Most playwrights' reputations depend on what they reveal about their characters; one has left that his (Pinter's) depends on what he (Pinter) does not reveal'" (1982, p. 180).

Old Times begins imaginatively with a strong visual metaphor that evokes the central theme of the play. The strange, paradoxical, almost invisible backstage presence of Anna, who is actually being awaited by the couple as an expected guest, behind the two on-stage characters Deeley and Kate, and the triangle of the characters thus formed gives out an instant symbolic meaning. It is thus the past exists in the present through memory, and as such past is capable of exercising palpable and potential impact on the present. This visual metaphor having introduced us to the Pinter's territory of Old Times' dramatic dialogue steadily pursues the theme that has been explored all through the action of the play. So the past is already gathered into the present through the shadowy figure of Anna silhouetted against the window. At the given moment Anna comes forward the dimly lit backstage area into the middle of the conversation going on between Deeley and Kate. Anna's sudden surfacing is an excellent example of Pinter's effective theatre. Though Anna was physically present on the stage, the dramatist alerts the audience to her presence only at the crosssection when the present meets the past, and Anna step into the limelight to make both Kate and Deeley aware of herself.

\section{ARGUMENT}

Old Times reflects Pinter's concern with poetic, cosmic truths. It is concerned with the basic human condition rather than with mere factual details about people. Such details, being highly relative in nature, can never be really trusted. As Pinter observes.

I suggest there can be no hard distinctions between what is real and what is unreal, nor between what is true and what is false. A thing is not necessarily either true or false; it can be both true and false (1986, p. 11).

According to Lowe (2006):

If we are to talk about truth, we must make some decisions about the nature of truth-bearers. But we needn't be monistic about truth-bearers: we needn't maintain that all truth-bearers belong to a single, unified ontological category. We can be pluralistic and allow that, in their own ways, such diverse entities as sentences, beliefs, and propositions may qualify as truth-bearers. But isn't there then a danger of truth itself being fragmented - a danger that we shall have to operate with different conceptions of truth when speaking of the various different kinds of truth-bearer? Not necessarily, so long as we can maintain that one kind of truth-bearer has primacy: that there are 'primary' as well as 'secondary' truth-bearers. For then we can regard truth in the primary sense as a property of the primary truth-bearers and define truth in various secondary senses in terms of primary truth. For instance, we can say that truth in the primary sense is truth of a proposition and define the truth of a sentence as the truth of the proposition that it expresses and the truth of a belief as the truth of the proposition that constitutes its intentional content. (p. 178)

This is what we may term as Pinter's poetic quest for the essence as against superficial factual particularities of mundane events. He has used poetic techniques along with cognate phrases and has put maximum pressure on every word. He tends to be poetic in the deeper sense. No specific and vivid literal meaning can be abstracted from his plays, such as Old Times. How the full effect of Pinter's dramatic dialogue is absorbed in the theatre is clearly stated by the first night reviewer. He refers to the important moments which become dramatically relevant and meaningful on the stage: 'Do you drink brandy? Asks Deeley. Vivien Merchant's pause before replying that she would love some is just sufficient to remind you that on Pinter territory, every question is an attempt to control and every answer a swift evasion'” (Bryden, 1971, p. 27).

Pinter's mistrusts what is often naively taken for granted as a true confession of past actions, events or motives. Anna's words to Deeley confirm this mistrust: "There are some things one remembers even though they may never have happened" (Pinter, pp. 27-28). What Anna says to Deeley finds a close parallel in Pinter's monologue: "You often act as if the Balls pond Road and the lovely ebony lady never existed, as if the rain in the light on the pavements in the twilight never existed, as if our sporting and intellectual life never was', (p. 273).

Whatever the playwrights of the conventional realistic plays wish to convey, is conveyed through words which do not normally have any sub-textual undercurrent. In Pinter, however, the sub-text is of utmost importance, for he believes: "language...is a highly ambiguous business. So often, below the words spoken, is the thing known and unspoken" (Pinter, 1986, p. 13). The dialogue of Old Times shows that the playwright exploits fully the ambiguities and deceits inherent in spoken language, and thereby achieves his own kind of realistic effect. Between Pinter's “'lack of biographical data [about his characters, Deeley, Kate and Anna]... and the ambiguity of what they say lies a territory which is not only worthy of exploration but which is compulsory to explore", (p. 13).

Pinter uses words "meticulously and with constant awareness of the other language that can be locked underneath the spoken words"' (Brown, 1972, p. 51). This is a remarkable exercise in Old Times in the light of this awareness of the other language kept crucially confined beneath the words Deeley, Anna or Kate use. It is, therefore, interesting to see how Pinter's dramatic dialogue in Old Times serves the purpose of explaining the submerged ground behind 
Pinter's characters for whom truth is a variable, intangible thing. The vital issue for Pinter is the unverifiability of the past.

In a Pinter play there has always been a fundamental concern for the visualization of characters on the stage. Their gestures and movements greatly add to the significance of the dramatic dialogue between them. As Pinter observes:

What is so different about the stage is that you're just there, stuck, there are your characters stuck on the stage, you've got to live with them and deal with them... I find myself stuck with these characters who are either sitting or standing' (Bensky, 1972, pp. 22-23).

The dialogue at Anna's first appearance well serves its purpose:

Queuing all night, the rain, do you remember?...the Albert Hall, Convent Garden, what did we eat? To look, half the night, to do things we loved...to work in the morning, and to a concert, or the opera, or the ballet, that night, you haven't forgotten? And then riding on top of the bus... and the bus conductors, and then dashing for the matches' for the gas fire and then I suppose scrambled eggs, or did we? Who cooked? Both giggling and chattering, both huddling to the heat, then bed and sleeping, and all the hustle and bustle in the morning, rushing for the bus again for work...innocent girls, innocent secretaries, and then the night to come, and goodness knows what excitement in store, I mean the sheer expectation of it all, the looking-forwardness of it all, and so poor, but to be poor and young, and a girl, in London then....and the cafes we found, almost private ones, weren't they?...and does it still exist I wonder? Do you know? Can you tell me? (Pinter, pp. 13-14).

Anna is reconstructing the past by reminiscing about the past episodes of her living together with Kate in London as working girls decades ago. By doing so she provokes Kate to remember things, to dig up the memories of Kate's past from oblivion. The passage has nine notes of interrogation and not a single period. This characteristic of the dialogue signifies the impetuosity of Anna's verbally-manipulated provocation. The tension is well discerned and implies that the menace of the past is to run its course through the action of the play, and that by stirring the skeletons in the cupboard Anna shall exercise considerable influence over the present. The patterning of the dialogue, as Almansi and Henserson rightly point out, "has the effect of diachronic time, since, from the outset, past and present are both manifest on the stage simultaneously, though with a different status (light versus dark; centre of the room versus windows; foreground versus background)', (1983, p. 86).

Anna's dialogue at once establishes by its perceptibility whining overtone that it is dealing subtly with the synchronic. It seeks to describe the existing events, as against the diachronic or historical aspect of time. To elaborate this in proper perspective it may be said that for Kate, Anna represents a U-turn to past with emotional strings attached.

Anna refers to some very particular moments in the time-pocket as they did exist. Footfalls of those moments echo still in the memory. Kate's husband Deeley represents the immediate present with all its here-now-now appeal. As such Old Times does not expand the idea of the historical flux of time. In this play Pinter has put the space of the past as against the space of the present.

As the action of the play unfolds itself systematically through the dialogue which the three characters exchange between them, we find that Anna, Kate and Deeley too start delving, not mere nostalgically, but with some cautious moves, into the past by way of recollecting choicest episodes. As it gradually transpires, the audience discover that Deeley also knew both Anna and Kate as and when they lived and moved and shared an apartment house together in London of that time. Deeley says to Anna, "I wish I had known you both then" (Pinter, p. 16). This is cunningly ambiguous and false in vie of his, Thompson rightly says that Pinter "exploits to the full the ambiguities and deceits inherent in spoken language and achieves his own kind of realistic effect" (1985, p. 42). After a while the dialogue between Deeley and Anna about having met at the Wayfarers is noteworthy. The remembrances and references to past events by Anna and Deeley register their battle for gaining ground, or in other words a struggle for territory, and the territory is no other than Kate's body and mind. Pinter's dialogue engages the words in combat to set the dramatic pattern of intensification which underlines the Pinterian theatre. Ionesco advocated this intensification, having repudiated the descriptive well-made play:

A play does not consist in the description of the development of .... a story...a play is a structure that consists of a series of states of consciousness, or situations which become intensified, grow more and more dense, then get entangled (1960, p. 231).

The dialogue between Deeley and Anna is serving this dramatic purpose as each measured utterance of both Deeley and Anna tends to intensify the action and to find means of expression beyond language. This may be said to be a battle between time past represented by Anna and time present represented by Deeley.

It has been contended, "in Pinter, unlike in T.S. Eliot, there is no time future contained in the past," and also that "the characters... are cut off from their future by their unchristian despair" (Almansi and Henderson,1983, p. 86). It is difficult to agree. In Old Times, we find that for Kate time past did contain time future in the sense that she will have a background movement to turn to merge her future with her past in the surrealistic way, synthesizing the workings of her subconscious mind with the conscious one. On the other hand, the characters can hardly be said to be cut off from their future by their unchristian, non-religious despair. The dialogue with all its sub-texual pull establishes no much ennui or despair of life on the part of the trio, since they are not expressing ideas in terms of any realistic logicality. As regards Kate and Anna, no plausible despair may be traced. For Deeley it is defeat in retrieving and retaining Kate in the present with him. His is the abstention from movement. Gale observes that, "in Old Times Pinter has given us the 
dramatization of the famous opening lines of T.S. Eliot Four Quarters: Time present and time past' (1977, p. 188). It may, however, be pointed out that Old Times is not just the dramatization of these opening lines, but rather of the whole of Burnt Norton in which Eliot deals with the psyche of the unredemmable time, arriving at the realization. Only through time, time is conquered. In Old Times Pinter also deals with the same psyche of time as all the three characters appear to be caught in the form of limitation between un-being and being. This makes Hayman comment, "perhaps Pinter owes more to T.S. Eliot than has been recognized"' (1968, p. 45). Accordingly, much of the theatrical impact of Old Times is due to the suspense in trying to get at what really happened in the past and what sort of relationship existed between Anna, Kate and Deeley. Pinter expresses his view thus:

We don't carry labels on our chests, and even though they are continually fixed to us by others, they convince nobody. The desire for verification of the part of all of us, with regard to our own experience and the experience of others is understandable but cannot always be satisfied (1986, p. 11).

Old Times demonstrates through its dialogue that the search for the final truth about a character is likely to be an unfinished quest. Dialogue in the play fulfils a two-fold function: communicating the truth of the past, and the dramatic tension produced by the conflicting involvement of the three characters.

The entire dramatic dialogue of Old Times suggests that one can never be absolutely sure about the existence of the past in terms as one recapitulates it. The play is dominated by the past, being reminiscent of L.P. Hartley's novel The Gro-Between (1953) for which Pinter wrote the screenplay in January 1969. Its first line reads: "the past is a foreign country. They do things differently there". It is significant that Painter also wrote another screenplay in 1972Remembrances of Things Past - for Proust's epic novel A la Recherche du Temps Perdu. These two novels deal with the atmosphere of the past almost in the same manner as Old Times. Along with Proust and Hartley, Pinter concerns himself with mutability and the big question as to what past means to us. Pinter's concern has been distinctly manifested through the verbal idioms he has used in the play.

The past is no longer within reach, it has vanished into eternity for ever, only the memories remain. Memories are seldom any accurate recordings of the past, nor can they ever be regarded as an authentic photocopy or negative print of any past happening. Memories, more often than not, redefine the past - man having acutely undergone various stages of transformation along with the inexorable passage of time. As such, over and above the phenomena situation that forgetfulness is a condition of mind, one either distorts the past to hide or avoid what is uncomfortable or threatening; or, one re-creates an altogether imaginary or unsubstantial past in order to satisfy one's temporal psycho-moral needs.

It has been rightly said, "in Pinter words are...barbs to protect the weird enclosure of the self" (Almansi and Henderson, 1983, p. 12). Pinter himself strongly adheres to the idea, "the speech we hear is an indication of that which we don't hear. It is a necessary avoidance, a violent, sly, anguished or mocking smokescreen...that what takes place is a continual evasion, desperate re-argued attempts to keep ourselves to ourselves" (Pinter, 1986, pp. 14-16). In Old Times what Anna says is in tune with this statement of Pinter: "There are some things one remembers even though they may never have happened. There are things I remember which may never have happened but as I recall them o they take place" (pp. 27-28). As the characters themselves are not sure of what has exactly happened in their past, the audience or readers to whom important information is being communicated through dialogue between these characters, are left in a state of uncertainty. However, the response of the audience to the play also centres round the synthesis of the bits and pieces of information it has been provided with by the dialogue exchanged by the dramatic persons so as to establish certain realities about the past.

Dramatic dialogue in Old Times spells out the imprecise, unexplainable, unknown and unremembered or less remembered past in a context that does not prompt audience or readers to ask what really happened but rather to understand and feel that certain matters do remain imprecise, inexplicable, unknown and unremembered in the life of a person in this world. Kate and Anna make guesses about their past; either they remember or try to remember it. However, the accuracy of the remembrance does not dramatically matter. What matters is what happens. Kate, Anna, and Deeley are required to try to ascertain the truth which in a Pinter play remains ambiguous, undetermined, distorted and untrue. In this context, it has been pertinently observed:

the only thing we know about Pinter's characters is that they find communication not only difficult but terrifying... they continually try to evade the pitfalls of human intercourse, frequently resorting to a sort of bobbing and weaving in the face of all direct contact (Almansi and Henderson, 1983, p. 24).

So the characters do not like to come out of the maze of the past, as it happens in Old Times.

The tales remembered by the characters, one by Deeley and another by Anna, are of prime importance in creating the menace of the past palpably. These two reminiscences project the sharp angle of menace that has caused Kate to subdue her memories of her old and only friend, Anna. The information accruing from these memories suggests overtly that Anna and Kate have had a lesbian relation between them in the past. The dialogue involving Anna at many points in the play hints at this lesbian relationship. But there is no explicit dialogue refers to this possibility in more than one way.

Through his dramatic dialogue Pinter drops hints which can turn out to be clues in the mystery. Nevertheless, the trail of evidence ends in smoke without ever leading to any solution. Pinter knows how to bring his dialogue under control, making it mean exactly what he alone wishes it to mean or imply or insinuate. This is when Pinter's drama reaches the point where the horizontal axis of content intersects the axis of form. As Styan significantly points out, "the playwright 
knows that in the theatre he has our ears, and much of his appeal rests upon the feeling he wants us to hear in the voices of his actors, as distinct from the meaning of their words" (1985, p. 38).

Indeed, Pinter who is a consummate theatre personality as an actor, screenplay writer, director, knows that in the voice of the actors he has a most flexible instrument perfectly capable of communicating the sense. Bold aptly observes, "the rich verbal texture of Pinter's theatrical routine is inspired...by the experience of spending long hours in rehearsal where every utterance is under scrutiny and has to be delivered with dramatic impact" (1984, pp. 8-9). Character-actors accept the text as a theatrical challenge which they undertake to translate into vocal terms. When we read or listen to the dialogue of Old Times, we feel that it is not the words alone which make the play, but the vivid dramatic impressions which the words are capable of creating. Hall pertinently remarks, "There is a communication in the theatre which is beyond words, and which is actually concerned with direct feeling" (1986, p. 47). In Old Times the entire dialogue is feeling-oriented revolving round Deeley, Kate and the intruder, Anna.

Deeley is quite sensitive to Anna's innuendos and gets disturbed over her conscious attempt to shirk an avowal or a denial that she and Kate had been lovers. Consequently, as shown by the dramatic dialogue, he makes constant effort to extract some conclusive tell-tale information from her. As an example we may cite the following dialogue:

Anna: No one who lived here would want to go far, I would be afraid of going far, lest when I returned the house would be

Deeley: Lest?

Anna: What?

Deeley: The word lest. Haven't heard it for a long time [pause] (Pinter, p. 15).

The word "lest" used by Anna appears to have an indirect implication of a lesbian attachment, and its almost anagrammatized sound at once hits Deeley where it hurts. In the following dialogue the same thing happens again:

Anna: we used to plat them...late at night, lying on the floor....Sometimes I would look at her face, but she was quite unaware of my gaze.

Deeley: Gaze?

Anna: What?

Deeley: The word gaze. Don't hear it very often. (p. 15)

Again, the word "gaze" seems to have a homophonal association with the word "gay" which stands for homosexuality. On both these occasions, Deeley wants Anna to explain why she has chosen these particular words, which are for him rather awkwardly meaningful.

What strikes an attentive audience or reader is that Anna always makes use of her fig-leaf statements so much so that Deeley's suspense never ends, nor that of the audience. We do not learn unambiguously whether there had been any sexual tie between these two mysterious female characters. What the playwright himself has said in this context is noteworthy:

My characters tell me so much and no more, with reference to their experience, their aspirations, their motives, their history. Between my lack of biographical data about them and the ambiguity of what they say lies a territory... which it is compulsory to explore (1986, p. 13).

Before Pinter and other writers of the absurdist plays, what a character said on the stage was true for our purpose, unless we were given specific reasons for distrusting his words. Pinter, an absurdist playwright, rejects this convention of the well-made play. His characters are shot through with a very palpable indefiniteness. The impossibility of verifying reality becomes not only a source of dramatic suspense created and maintained through dramatic deliberately withholds information for which the audience craves, following his own theory, "The desire for verification is understandable, but cannot always be satisfied" (p. 11), the view may seem related to a metaphysical vision of the unity of opposites. But when Pinter elaborates that there are no hard distinctions between what is real and what is unreal, he is only saying that events reach us through our unreliable sense impressions.

The dialogue in Pinter's plays gives rise to uncertainties, doubts and contradictions. It shows that the ordinary and the realistic are inextricably intertwined with the irrational and the absurd. Esslin has underlined this subtlety with which a Pinter play works by pointing out that a Pinter audience gets confronted by the "images of the real world which are raised to metaphors of the human condition by a mysteriousness inherent in reality and the difficulties of drawing a line between the real, the imagined and the dream" (1986, p. 183).

\section{CONCLUSION}

In Old Times the dialogue is encased in a firm and stable monologic framework. It is established through verbal interactions between all the three characters that the reality of the past fades, and memory transforms real events into shadowy remnants of insubstantial experience. Pinter's dialogue quite deftly shows how contradictory are the lies which we tend to accept. Also by using a folded inconvoluted language pattern Pinter wants to make the meaning theatrically more luminous by provoking the audience to work out the implications so that it can recreate the meaning by carefully following the verbal exchanges. The characters in this play say nothing explicitly. Pinter finds people enigmatic, and his presentation of them, as an absurdist, remains an enigma. All the meanings of the play must be guessed only with the help of the clues which the dialogue provides. The dialogue requires the audience to read between the lines and grasps the meaning intuitively at the connotational level. Through the verbal exchanges between Anna, Kate and Deeley, Pnter 
has endeavoured to expose the lies which the audience believe to be the truth. Thus, it can be concluded that Pinter's dialogical design is woven around the reality he himself has experienced. Dialogic course of Pinter's drama moves towards man's subconscious mechanism, and helps in a subtle way to examine human relationships from diversified angles. His dialogue rejects the stereotype, and effectively raises doubt about the language of alienation and obfuscation. It underlines a subconscious reality behind the façade and the mask. Pinter's dialogue design carefully works at, constantly refers to, and effectively mirrors the submerged level of human consciousness.

\section{REFERENCES}

[1] Almansi, G, \& Henderson, S. (1983). Harold Pinter: contemporary Writers Series. London: Methuen.

[2] Barker, W. \& Tabachnich, S, T.(1973). Harold Pinter. Edinburgh: Oliver and Boyd.

[3] Bensky, L, M. (1972). Harold Pinter. An Interview, Pinter: A Collection of Critical Essays, ed: Arthur Ganz. Englewood Cliffs, NJ: Prentice-Hall.

[4] Bold, A. Ed. (1984, RPT. 1986) Harold Pinter. You Never Heard Such a Silence. London: Vision and Barnes and Noble.

[5] Brown, J, R. (1972). Theatre Language. London: Penguin.

[6] Bryden, R. (1971). Pinter's New Pacemaker, The Observer, June 6, 1971. Qtd. Plays in Review 1956-1980, ed. Gareth and Barbara.

[7] Lioyd Evans. (1985). British Drama and the Critics. London: Bastford Academic and Educational.

[8] Esslin, M. (1986). A Comparison to Post-War British Theatre. London: Croom Helm.

[9] Gale, S, H. (1977). Butter's Going Up: A Critical Analysis of Harold Pinter's Work. Druham, N.C: Duke University Press.

[10] Hall, P. (1986). Directing Pinter. Harold Pinter: A Selection of Critical Essays, ed. Michael Scott. London: Macmillan.

[11] Hayman, R. (1968). Harold Pinter. London: Heinmann.

[12] Joseph, J and Roberts, J, M, edition. (2004). Realism Discourse and Deconstruction. London: Routledge.

[13] Ionesco, E. (1960). "Pages de journal, “' Nouvelle Revue Francaise, Feb. 1960, p.231.

[14] Lowe. E.J. (2006). The Four-Category Ontology: A Metaphysical Foundation for Natural Science. Oxford: oxford university press.

[15] Kettle, A. (1953). An Introduction to the English Novel. London: Hutchingson.

[16] Nightingale, B. (1982). An Introduction to Fifty Modern British Plays. London: Pan.

[17] Pinter, H. (1986).Writing for the Theatre, a speech made by Pinter at the National School of Drama festival in Bristol in 1962. Pinter Plays: London: Methuen, p.11.

[18] Pinter, H. (1981). Plays: One, Two, Three and Four. London: Methuen.

[19] Stayan, J.L. (1985). The Dramatic Experience. Cambridge: Cambridge University Press.

[20] Thompson, D, T. (1985). The Players' Playwright. London: Macmillan.

Noorbakhsh Hooti is currently an Assistant Professor of English Language and Literature at Kermanshah Razi University, Iran. $\mathrm{He}$ is a member of the research committee of the College of Humanities and Literature, Razi University. His main interests of research are drama, Short Story and Novel. He has been engaged in teaching English language and Literature for more than fifteen years. He holds Ph. D. in English Language and Literature, M. A. in English Language and Literature, and B.A in English Language and Literature. He has published a number of books, Research Projects, and articles in his areas of interest in academic journals. 